\title{
Evidence of DNA Replication Licensing and Paternal DNA Degradation by MCM7 and ORC2 in the Mouse One-cell Embryo
}

\author{
Chang Jin Kim ${ }^{1}$, Tae Hoon Kim², Eun-Woo Lee ${ }^{3}$ and Kyung-Bon Lee ${ }^{1, \dagger}$ \\ ${ }^{1}$ Department of Biology Education, College of Education, Chonnam National University, Gwangju 61186, Korea \\ ${ }^{2}$ Department of Food Science and Biotechnology, College of Engineering, Daegu University, Gyeongsan 38453, Korea \\ ${ }^{3}$ Division of Applied Bioengineering, College of Engineering, Dong-eui University, Busan 47340, Korea
}

This study was investigated to test whether paternal DNA that was destined for degradation was properly licensed by testing for the presence of mini-chromosome maintenance protein (MCM) 7 and origin recognition complex (ORC) 2 in the paternal pronuclei. ORC2 is one of the first licensing protein to come on and MCM7 is one of the last licensing protein to come on. Zygotes were prepared by injection of control and treated sperm injection (ICSI). To control for DNA breakage, epididymal spermatozoa were treated with DNase I to fragment the DNA, then injected into oocytes. The presence of MCM7 and ORC2 in the pronuclei of mouse zygotes was tested by immunohistochemistry, just before the onset of DNA synthesis, at $5 \mathrm{~h}$ after fertilization, and after DNA synthesis began, at $9 \mathrm{~h}$ post fertilization. We found that in all cases, both MCM7 and ORC2 were present in both pronuclei at $5 \mathrm{~h}$ after sperm injection, just before DNA synthesis began. This indicates that no matter how extensive the DNA damage, recruitment of licensing proteins to the origins of replication was not inhibited. Sperm DNA fragmentation does not prevent licensing of DNA replication origins. Furthermore, the embryo recognizes DNA that is damaged by nucleases. Our data indicate that the one-cell embryo does harbor a mechanism to prevent the replication of severely damaged DNA from spermatozoa, even though the embryos do not undergo classical apoptosis.

Key Words: MCM7, ORC2, DNA breakage, DNA fragmentation, DNA replication

\section{서 론}

포유동물의 1 세포기 수정란의 경우에는 독특한 DNA 복제 라이센싱 기작으로 인해 DNA 복제와 관련된 다양 한 추가적 연구를 하는데 매우 적합한 모델이다. 포유동 물의 DNA 염기는 대략 60 억의 염기쌍으로 이루어져 있 다(Pardoll et al., 1980; Vogelstein et al., 1980). 이렇게 많은 염 기쌍은 수정란부터 시작해서 이 개체가 생존하고 있는 동 안 무수히 많은 복제가 이루어지며, 유전체 전체에 걸쳐 수많은 지점에서 서로 다른 시기에 개별적으로 복제가 이
루어진다(Stubblefield, 1975; Pardoll et al., 1980). 박테리아 (Lemon and Grossman, 1998)나 포유동물(Pardoll et al., 1980) 은 DNA 복제가 시작되는 부위인 복제기점이라는 고정적 인 장소에서 복제복합체(replication complex)가 형성된다. 그 후, 이 복제복합체가 주형 $\mathrm{DNA}$ 를 끌어당기면서 복제 가 일어난다. 박테리아의 경우에 복제기점을 인식하는 방 법으로 특정 DNA 서열을 인식하여 복제복합체가 형성되 지만, 포유동물의 복제기점은 DNA 서열에 좌우되지 않는 다(Gilbert, 2001; Robinson and Bell, 2005; Costa and Blow, 2007). 포유동물의 복제기점은 잠재적인 복제기점에서 사 전복제복합체(pre-replication complex, pre-RC)가 형성되어야

* Received: October 13, 2017 / Revised: November 6, 2017 / Accepted: November 7, 2017

${ }^{\dagger}$ Corresponding author: Kyung-Bon Lee. Department of Biology Education, College of Education, Chonnam National University, Gwangju 61186, Korea. Tel: +82-62-530-2507, Fax:+82-62-530-2509, e-mail: kblee@jnu.ac.kr (C) The Korean Society for Biomedical Laboratory Sciences. All rights reserved.

(c) This is an Open Access article distributed under the terms of the Creative Commons Attribution Non-Commercial License (http://creativecommons.org/licenses/by-nc/3.0/) which permits unrestricted non-commercial use, distribution, and reproduction in any medium, provided the original work is properly cited. 
복제기점으로 인식될 수 있다. 이처럼 복제기점에서의 사 전복제복합체 형성과정을 DNA 복제 라이센싱이라 한다. 복제 라이센싱 과정의 시작은 잠재적 복제기점에 복제 인식복합체(origin recognition complex, ORC)의 결합에 의 해 시작된다(Coster et al., 2014; Ticau et al., 2015). 복제인식 복합체의 결합은 복제 전 $\mathrm{G} 1$ 기 동안에 라이센싱 단백질 (licensing protein)이라고 명명되는 일련의 단백질들이 DNA 상에 정확한 순서로 결합되는 기작에 의해 이루어진다 (Blow and Laskey, 1988; Leno et al., 1992; Blow, 1993). 라이 센싱 과정에 참여하는 일련의 단백질은 $\mathrm{ORC1} \mathrm{ORC6까}$ 지 6개의 소단위체 단백질이 복제인식복합체를 형성하고 여기에 추가적으로 $\mathrm{CDT} 1, \mathrm{CDC} 6, \mathrm{MCM} 2$ 7이 결합하여 사전복제복합체를 형성함으로써 라이센싱이 이루어진다 (Takeda and Dutta 2005; Krude, 2006).

구체적 $\mathrm{DNA}$ 복제 라이센싱 과정은 $\mathrm{ORC} 2, \mathrm{ORC} 3, \mathrm{ORC} 5$ 로 불리는 세 개의 소단위체가 세포질에서 우선 복합체를 형성한 후, ORC4, ORC6과 추가적으로 결합하여 핵으로 수송된다(Ghosh et al., 2011). 핵으로 수송된 ORC2 6은 ORC1이 결합하기 전(Takeda et al., 2005) 또는 후(Ghosh et al., 2011)에 복제기점에 결합한 후, 세포 주기 동안에는 DNA에 계속 결합하여 남아 있다(Depamphils, 2005; Thomae et al., 2008). ORC1이 ORC2 6에 결합한 후 이 복합체에 $\mathrm{CDT} 1, \mathrm{CDC} 6$ 이 차례로 결합하고 그 후 mini-chromosome maintenance protein (MCM)2-7 복합체가 결합함으로써 복 제기점에서 완벽하게 사전복제복합체가 형성된다(Rao and Stillman, 1995; Rowley et al., 1995; Speck et al., 2005). G1기 동안에 복제기점에서의 사전복제복합체 형성의 완료는 DNA 복제시작을 위한 준비과정인 라이센싱이 이루어진 것으로 간주되고 이 후 일련의 과정을 거쳐 복제가 시작 된다.

마우스를 포함한 일부 포유동물의 경우 정자 형성과정에 서 환경 또는 화학적 스트레스에 노출되면 DNA 이중나 선 절단(DNA double-stranded break)이 일어난다(Yamauchi et al., 2007). 마우스 정자에 2가 양이온인 $\mathrm{MnCl}_{2}$ 와 $\mathrm{CaCl}_{2}$ 을 처리하면 이러한 $\mathrm{DNA}$ 이중나선 절단이 잘 일어나는 것으로 보고된 바 있다(Yamauchi et al., 2007). 마우스 정자 에서 발생하는 DNA 이중나선의 절단은 크게 2 단계의 과 정으로 나눌 수 있다. 첫 번째 과정은 Topoisomerase II B (TOP2B)에 의해 대략 $25 \sim 50 \mathrm{~kb}$ 크기의 절편으로 나뉘는 데 이러한 DNA 절편을 정자 염색질 조각(sperm chromatin fragmentation, $\mathrm{SCF}$ )이라 하고 이러한 $\mathrm{SCF}$ 는 $\mathrm{EDTA}$ 에 의해 다시 회복이 가능하며(Shaman et al., 2006) 이러한 회복된
DNA 절편을 SCF-religated라 한다. 두 번째 과정으로 정자 내 핵산분해효소에 의해 광범위하게 DNA degradation이 일어나며 이러한 degradation이 일어난 정자 $\mathrm{DNA}$ 를 정자 DNA degradation (sperm chromatin degradation, SDD)이라고 부른다(Shaman et al., 2006). 특히 체외에서 마우스 정자에 $\mathrm{MnCl}_{2}$ 와 $\mathrm{CaCl}_{2}$ 을 처리할 때 정자가 존재하는 위치에 따라 $\mathrm{SCF}$ 와 $\mathrm{EDTA}$ 에 의한 회복 정도가 달리 일어난다. 그 예로 써 vas deferens sperm이 epididymal sperm보다 더욱 광범위 하게 SCF가 일어나며(Yamauchi et al., 2007), EDTA에 의한 회복도 vas deferens sperm보다 epididymal sperm에서 거의 완벽하게 회복되었다(Shaman et al., 2006). 이는 vas deferens sperm에 핵산분해효소가 높은 농도로 존재하기에 epididymal sperm보다 DNA degradation 정도가 더 심하게 일어 남을 알 수 있다(Yamauchi et al., 2007). 따라서 본 연구에 서는 수정란의 degradation이 예정된 부계 전핵과 모계 전 핵에서 $\mathrm{MCM} 7$ 과 $\mathrm{ORC} 2$ 의 존재 여부를 $\mathrm{DNA}$ 복제 전과 후에 각각 확인하여 DNA 복제 라이센싱이 되는지를 확 인하였다.

\section{재료 및 방법}

\section{공시재료}

본 연구에서 이용된 마우스는 $\mathrm{B} 6 \mathrm{D} 2 \mathrm{~F} 1$ (C57BL/6N X $\mathrm{DBA} / 2$ )으로 온도 $23 \pm 1{ }^{\circ} \mathrm{C}$, 습도 $50 \pm 1 \%$ 내외, 그리고 12 시간 명암 주기(light 8:00 20:00, dark 20:00 8:00)로 유지 되는 동물 사육실에서 사육하였다. 1 주 간의 적응 기간 동 안 실험동물에게 음식과 물을 자유로이 공급하였다. 모든 실험계획은 전남대학교 동물윤리위원회의 규정에 의거해 서 실험하였다. 본 재료 및 방법에서 별도로 회사를 기재 하지 않은 시약은 모두 Sigma-Aldrich 사의 제품을 사용 하였다.

\section{정자 준비}

8 12주령의 마우스의 epididymis 및 vas deferens의 내강 내용물을 분리 추출하여 HEPES-CZB (HCZB) 배양액에 넣었다. 정자를 $\mathrm{HCZB}$ 배양액에 넣은 후 피펫팅으로 고르 게 섞어준 후 control, SCF 및 SCF-religated 그룹으로 각각 나누었다. Control 그룹의 정자는 실온에서 90 분 동안 배양 하였다. SCF 그룹과 SCF-religated 그룹은 $10 \mathrm{mM} \mathrm{MnCl}_{2}$ 와 $\mathrm{CaCl}_{2}$ 을 첨가한 후 실온에서 90 분 동안 배양하였다. 그 후 SCF-religated 그룹에는 $100 \mathrm{mM} \mathrm{EDTA}$ 를 첨가하고 다시 실온에서 30 분 동안 추가 배양하였다. 배양 후 정자들은 
바로 ICSI에 이용하였다.

\section{과배란 유도 및 난자 채취}

8 12주령의 성숙한 암컷 마우스에 $5 \mathrm{IU}$ eCG를 복강 주사하고, 48 시간 후 $5 \mathrm{IU} \mathrm{hCG}$ 를 주입하여 과배란을 유도 하였다. $\mathrm{hCG}$ 주입 후 14 15시간에 난관을 절개하여 배란 된 난구세포-난자 복합체를 방출시켜 $0.1 \%$ hyaluronidase 가 함유된 $\mathrm{HCZB}$ 배양액에 침지하였다. 난구세포가 분리 된 난자는 $\mathrm{HCZB}$ 배양액으로 3회 세척 후 즉시 ICSI에 이용하였다.

\section{세포질 내 정자미세주입}

ICSI는 Szczygiel와 Yanagimachi (2003)의 방법을 변형하 여 실시하였다. 먼저 $60 \mathrm{~mm}$ petri dish (Falcon, NJ, USA)에 $12 \%$ polyvinyl pyrolidone (PVP)가 포함된 $\mathrm{HCZB}$ 배양액 소 적을 만든 후 이와 동일한 부피의 정자 부유액 소적을 만들어 두 소적을 섞어주었다. 그리고 준비된 난자 1 개 당 1 개의 정자 머리를 주입하였다. 난자에 정자 머리 주 입과정은 Micromanipulators (Micromanipulator Transferman, Eppendorf, Germany)와 Piezo-electric actuator (Prime Tech, Tsukuba, Japan)을 이용하여 실시하였다. 제일 먼저 하나의 정자를 주입용 피펫으로 꼬리를 우선 흡인한 후 압전 전 류를 흘려 중편과 꼬리를 떼어내었다. 그 후 머리를 주입 용 피펫으로 재 흡인한 후 난자 안에 즉시 주입하였다.

\section{체외 배양}

$\mathrm{ICSI}$ 를 이용하여 정자가 주입된 난자는 $37^{\circ} \mathrm{C}, 5 \% \mathrm{CO}_{2}$ 조건하에 $\mathrm{CZB}$ 배양액으로 배양하였다. 1세포기 수정란에 서 $\mathrm{MCM} 7, \mathrm{ORC} 2$ 발현 확인은 ICSI 후 각각 5,9 시간째에 이를 확인하였다.

\section{$\mathrm{MCM} 7$ 및 $\mathrm{ORC2}$ 의 면역형광염색}

마우스 1세포기 수정란을 CZB 배양액에 배양한 후 실 온에서 30 분 동안 $4 \%$ 파라포름알데히드로 고정하였다. 파라포름알데히드 저장용액은 고정 전 $16 \%$ 저장용액(Alfa Aesar stock no. 43368)을 희석하여 4\%로 만든 후 하룻밤 동안 $4{ }^{\circ} \mathrm{C}$ 에 보관한 후 이용하였다. 고정 후, 세포를 씻어 낸 후 10 분 동안 $0.1 \%$ Tween이 함유된 PBS (PBST)로 2회 세척하였다. 그 후 1 세포기 수정란을 15 분 동안 $0.5 \%$ Triton $\mathrm{X}-100$ 으로 permeabilization 시킨 후 $0.5 \% \mathrm{BSA}$ 가 함유된 $\mathrm{PBST}$ 로 10 분씩, 2 회 세척하였다. 실온에서 1시간 동안 $\mathrm{BSA}$ 로 blocking 후 $4^{\circ} \mathrm{C}$ 에서 하룻밤 동안 1:300으로 희석
시킨 1 차 항체에 배양하였다. 배양 후 1 세포기 수정란을 $0.5 \% \mathrm{BSA}$ 가 함유된 PBST로 10 분씩 2회 세척하고 1 시간 동안 실온에서 $1: 1,000$ 으로 희석된 형광물질이 붙어있는 2 차 항체가 부착되도록 배양하였다. 형광표지 후, 1 세포기 수정란을 PBST로 10 분씩, 3 회 세척하였다. 슬라이드글 라스에 ProLong Gold antifade reagent with DAPI (P-36931, Invitrogen, USA)을 떨어뜨려 소적을 만들고 수정란을 투여 한 후, 커버글라스로 덮은 후 형광현미경으로 관찰하였다.

1 차 항체로 $\mathrm{ORC} 2$ 의 경우 anti-ORC2 (sc-13238, Santa Cruz Biotechnology, USA)를 이용하였으며, MCM7의 경우에 는 anti-MCM7 (sc-46687, Santa Cruz Biotechnology, USA)을 사용하였다. 2차 항체로 Alexa Fluor 488 (A11078, Invitrogen, USA)과 Alexa Fluor 546 (A21085, Invitrogen, USA)을 사용 하였다.

\section{통계 분석}

본 연구에서는 각 실험군에 대하여 4회 이상 반복실험 을 실시하였으며, 얻어진 모든 실험 결과의 통계처리는 SPSS software (Version 13.0)를 이용한 일원분산분석법으 로 처리구간 유의성을 검정하였으며, $P<0.05$ 의 유의성만 을 통계학적 차이가 있는 것으로 인정하였다.

\section{결 과}

Epididymal sperm을 이용하여 만든 1세포기 수정란에서 $\mathrm{DNA}$ 합성 전인 정자 주입 후 5시간째 $\mathrm{MCM}$ 7과 $\mathrm{ORC} 2$ 의 발현 결과는 Fig. 1 및 Table 1과 같다. Epi-Con (epididymal sperm injection-control), Epi-SCF 및 Epi-SCF-religated 그 룹 모두 부계와 모계 전핵 양쪽에서 $\mathrm{MCM} 7$ 과 $\mathrm{ORC} 2$ 가 발 현된 경우는 $100 \%$ 였다. 부계 전핵이나 모계 전핵에서만 $\mathrm{MCM} 7$ 과 $\mathrm{ORC} 2$ 가 각각 발현된 경우는 나타나지 않았다. DNA 합성이 진행 중인 정자 주입 후 9시간째에 $\mathrm{MCM} 7$ 과 $\mathrm{ORC} 2$ 가 발현된 결과는 Fig. 3 및 Table 3 과 같다. 이 역시 Epi-Con, Epi-SCF 및 Epi-SCF-religated 그룹 모두 부 계와 모계 전핵 양쪽에서 $\mathrm{MCM} 7$ 과 $\mathrm{ORC} 2$ 가 발현된 경우 는 $100 \%$ 였다. 부계 전핵이나 모계 전핵에서만 $\mathrm{MCM} 7$ 과 $\mathrm{ORC} 2$ 가 각각 발현된 경우는 나타나지 않았다.

Vas deferens sperm을 이용하여 만든 1세포기 수정란에서 $\mathrm{DNA}$ 합성 전인 정자 주입 후 5시간째 $\mathrm{MCM}$ 7과 $\mathrm{ORC} 2$ 의 발현 결과는 Fig. 2 및 Table 2와 같다. 이 역시 epididymal sperm을 주입한 경우와 마찬가지로 Vas-Con (vas deferens sperm injection-Control), Vas-SCF 및 Vas-SCF-religated 그룹 
Table 1. MCM7 and ORC2 expression at $5 \mathrm{~h}$ after epididymal sperm injection into mouse oocyte (Before DNA synthesis)

\begin{tabular}{|c|c|c|c|c|c|}
\hline & \multirow[b]{2}{*}{ Group } & \multirow{2}{*}{$\begin{array}{c}\text { No. of injected } \\
\text { oocytes }\end{array}$} & \multicolumn{3}{|c|}{ No. of zygotes (\%) } \\
\hline & & & $\begin{array}{l}\text { Stained with } \\
\text { MPN only }\end{array}$ & $\begin{array}{l}\text { Stained with } \\
\text { FPN only }\end{array}$ & $\begin{array}{l}\text { Stained with } \\
\text { MPN and FPN }\end{array}$ \\
\hline \multirow{3}{*}{ MCM 7} & Control & 113 & $0(0.0)$ & $0(0.0)$ & $113(100)$ \\
\hline & $\mathrm{SCF}$ & 110 & $0(0.0)$ & $0(0.0)$ & $110(100)$ \\
\hline & SCF-religated & 103 & $0(0.0)$ & $0(0.0)$ & $103(100)$ \\
\hline \multirow{3}{*}{ ORC2 } & Control & 113 & $0(0.0)$ & $0(0.0)$ & $113(100)$ \\
\hline & $\mathrm{SCF}$ & 106 & $0(0.0)$ & $0(0.0)$ & $106(100)$ \\
\hline & SCF-religated & 104 & $0(0.0)$ & $0(0.0)$ & $104(100)$ \\
\hline
\end{tabular}

MPN: male pronuclei, FPN: female pronuclei.

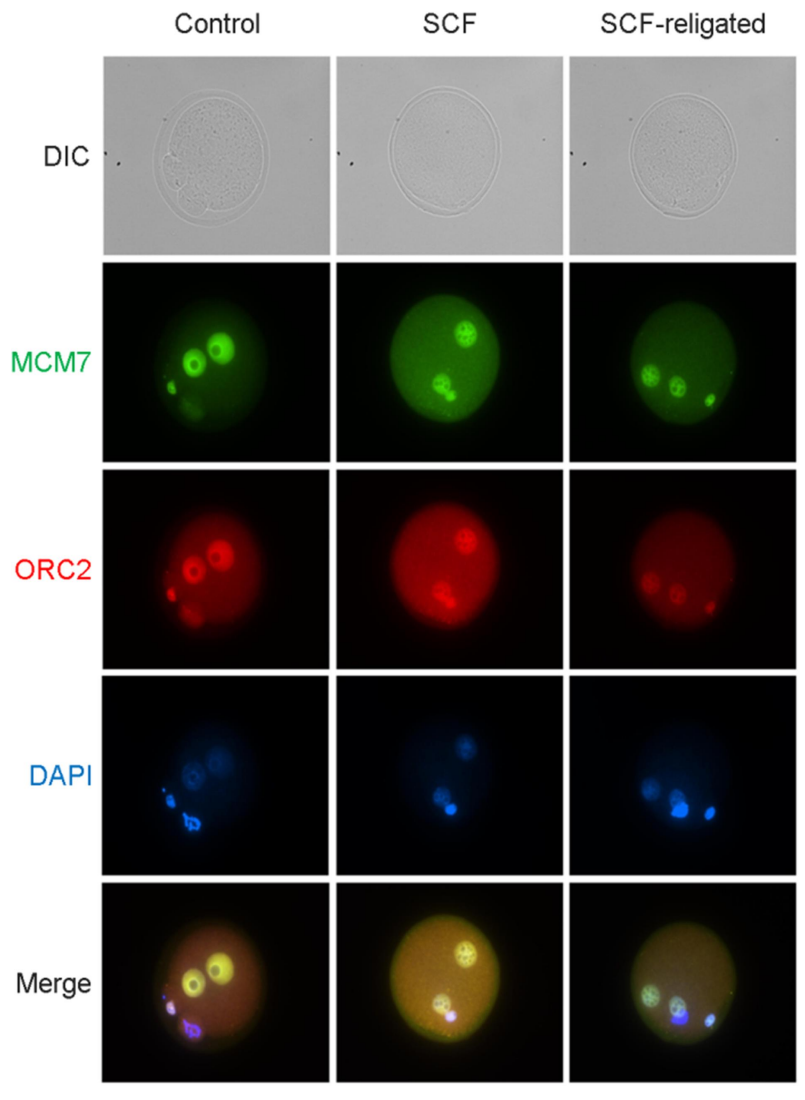

Fig. 1. Immunocytochemical localization of $\mathrm{MCM} 7$ and $\mathrm{ORC} 2$ in mouse one-cell embryos at $5 \mathrm{~h}$ after epididymal sperm injection into mouse oocyte (Before DNA synthesis). Embryos were fixed and double stained with antibodies to MCM7 (Green) and ORC2 (Red). Pronuclei were also stained with DAPI (Blue), and then visualized by confocal microscopy.

모두 부계와 모계 전핵 양쪽에서 $\mathrm{MCM} 7$ 과 $\mathrm{ORC} 2$ 가 발 현된 경우는 $100 \%$ 였다. 부계 전핵이나 모계 전핵에서만

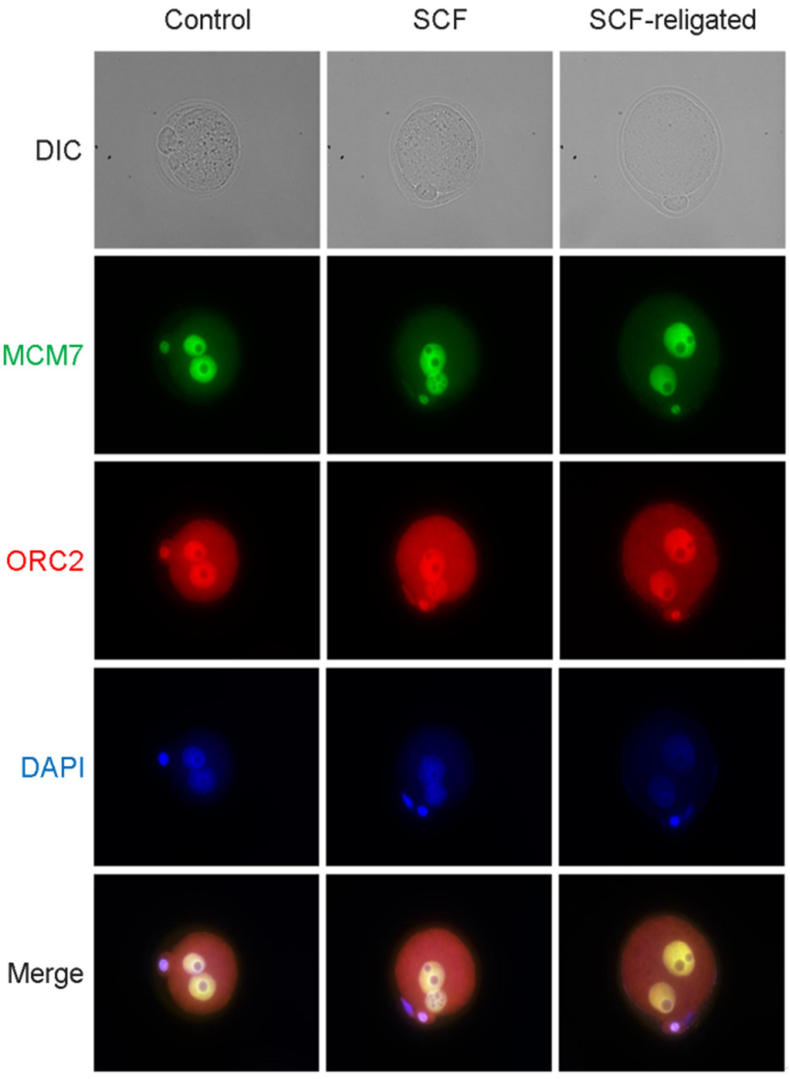

Fig. 2. Immunocytochemical localization of MCM7 and $\mathrm{ORC} 2$ in mouse one-cell embryos at $9 \mathrm{~h}$ after epididymal sperm injection into mouse oocyte (During DNA synthesis). Embryos were fixed and double stained with antibodies to MCM7 (Green) and ORC2 (Red). Pronuclei were also stained with DAPI (Blue), and then visualized by confocal microscopy.

$\mathrm{MCM} 7$ 과 $\mathrm{ORC} 2$ 가 각각 발현된 경우는 나타나지 않았다. 또한 정자 주입 후 9시간째(DNA 복제 진행 중)에 $\mathrm{MCM} 7$ 
Table 2. MCM7 and ORC2 expression at $9 \mathrm{~h}$ after epididymal sperm injection into mouse oocyte (During DNA synthesis)

\begin{tabular}{|c|c|c|c|c|c|}
\hline & \multirow[b]{2}{*}{ Group } & \multirow{2}{*}{$\begin{array}{l}\text { No. of injected } \\
\text { oocytes }\end{array}$} & \multicolumn{3}{|c|}{ No. of zygotes (\%) } \\
\hline & & & $\begin{array}{l}\text { Stained with } \\
\text { MPN only }\end{array}$ & $\begin{array}{l}\text { Stained with } \\
\text { FPN only }\end{array}$ & $\begin{array}{l}\text { Dtained with } \\
\text { MPN and FPN }\end{array}$ \\
\hline \multirow{3}{*}{ MCM7 } & Control & 112 & $0(0.0)$ & $0(0.0)$ & $112(100)$ \\
\hline & $\mathrm{SCF}$ & 112 & $0(0.0)$ & $0(0.0)$ & $112(100)$ \\
\hline & SCF-religated & 110 & $0(0.0)$ & $0(0.0)$ & $110(100)$ \\
\hline \multirow{3}{*}{ ORC2 } & Control & 113 & $0(0.0)$ & $0(0.0)$ & $113(100)$ \\
\hline & SCF & 105 & $0(0.0)$ & $0(0.0)$ & $105(100)$ \\
\hline & SCF-religated & 113 & $0(0.0)$ & $0(0.0)$ & $113(100)$ \\
\hline
\end{tabular}

MPN: male pronuclei, FPN: female pronuclei.

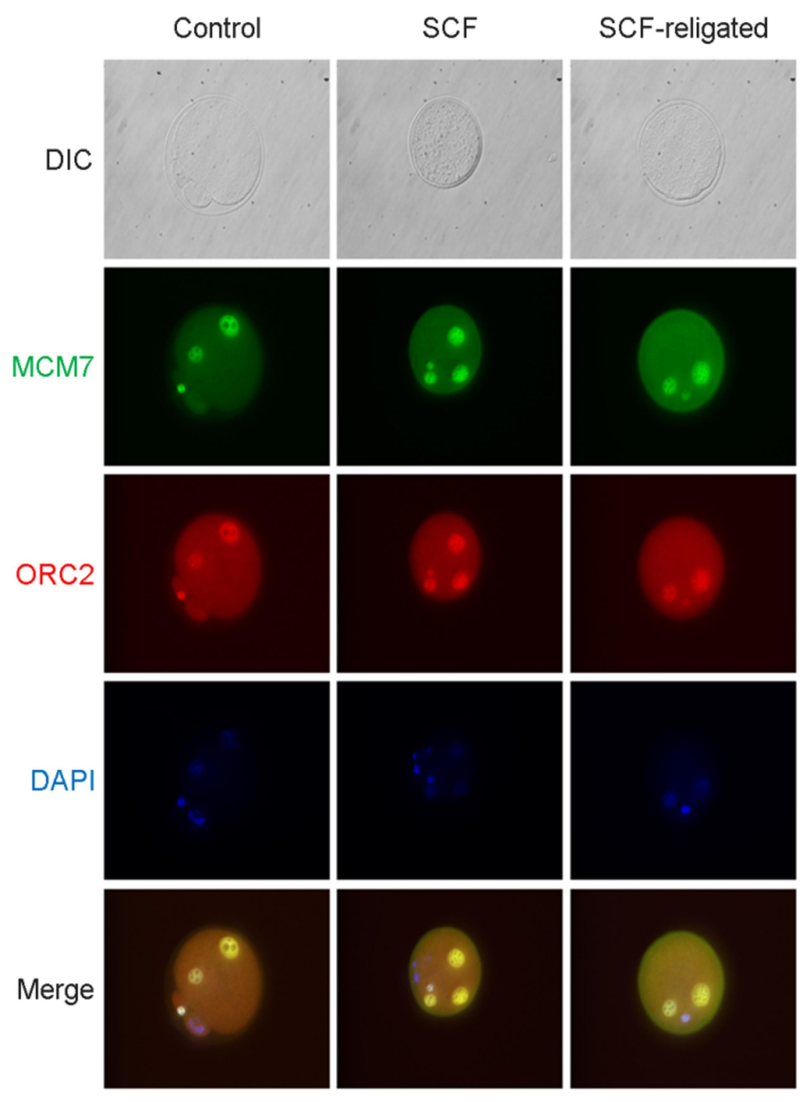

Fig. 3. Immunocytochemical localization of MCM7 and ORC2 in mouse one-cell embryos at $5 \mathrm{~h}$ after vas deferens sperm injection into mouse oocyte (Before DNA synthesis). Embryos were fixed and double stained with antibodies to MCM7 (Green) and ORC2 (Red). Pronuclei were also stained with DAPI (Blue), and then visualized by confocal microscopy.

과 $\mathrm{ORC} 2$ 를 관찰한 결과는 Fig. 4 및 Table 4와 같다. VasCon, Vas-SCF 및 Vas-SCF-religated 그룹 모두 부계와 모계

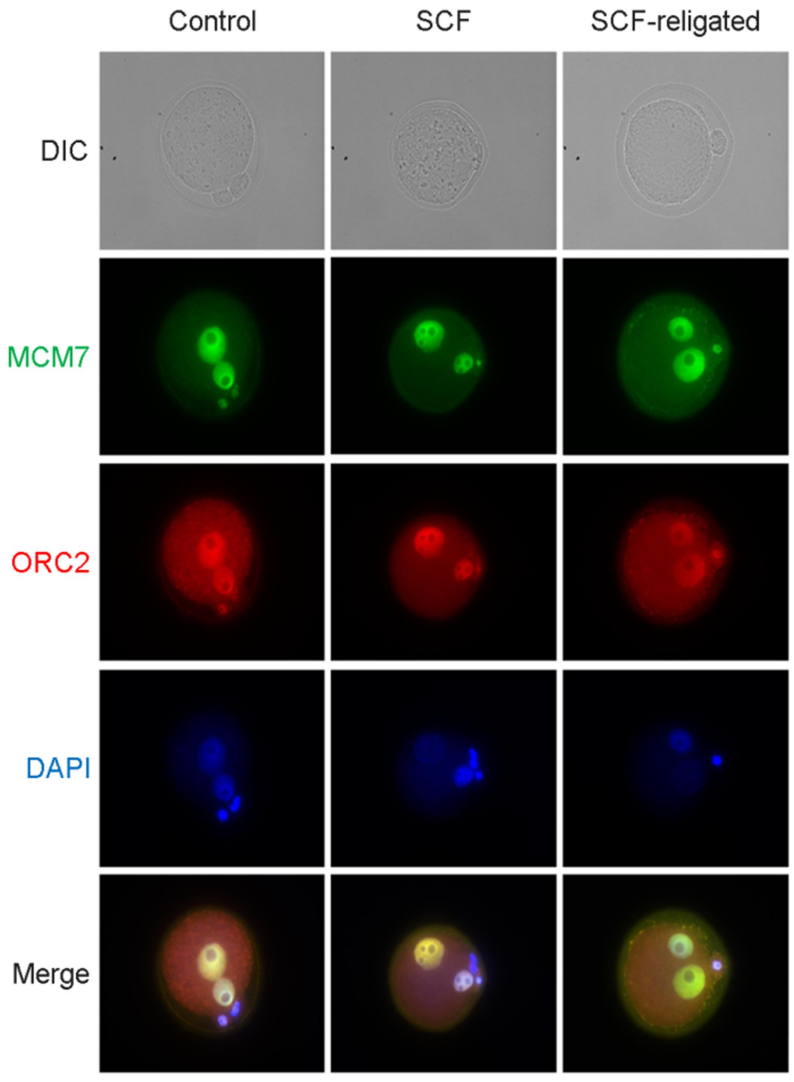

Fig. 4. Immunocytochemical localization of MCM7 and ORC2 in mouse one-cell embryos at $9 \mathrm{~h}$ after vas deferens sperm injection into mouse oocyte (During DNA synthesis). Embryos were fixed and double stained with antibodies to MCM7 (Green) and ORC2 (Red). Pronuclei were also stained with DAPI (Blue), and then visualized by confocal microscopy.

전핵 양쪽에서 $\mathrm{MCM} 7$ 과 $\mathrm{ORC} 2$ 가 관찰된 경우는 $100 \%$ 였 다. 부계 전핵이나 모계 전핵에서만 $\mathrm{MCM} 7$ 과 $\mathrm{ORC} 2$ 가 각 
Table 3. MCM7 and ORC2 expression at $5 \mathrm{~h}$ after vas deferens sperm injection into mouse oocyte (Before DNA synthesis)

\begin{tabular}{|c|c|c|c|c|c|}
\hline & \multirow[b]{2}{*}{ Group } & \multirow{2}{*}{$\begin{array}{c}\text { No. of injected } \\
\text { oocytes }\end{array}$} & \multicolumn{3}{|c|}{ No. of zygotes (\%) } \\
\hline & & & $\begin{array}{l}\text { Stained with } \\
\text { MPN only }\end{array}$ & $\begin{array}{l}\text { Stained with } \\
\text { FPN only }\end{array}$ & $\begin{array}{l}\text { Stained with } \\
\text { MPN and FPN }\end{array}$ \\
\hline \multirow{3}{*}{ MCM7 } & Control & 110 & $0(0.0)$ & $0(0.0)$ & $110(100)$ \\
\hline & $\mathrm{SCF}$ & 104 & $0(0.0)$ & $0(0.0)$ & $104(100)$ \\
\hline & SCF-religated & 94 & $0(0.0)$ & $0(0.0)$ & $94(100)$ \\
\hline \multirow{3}{*}{ ORC2 } & Control & 108 & $0(0.0)$ & $0(0.0)$ & $108(100)$ \\
\hline & $\mathrm{SCF}$ & 107 & $0(0.0)$ & $0(0.0)$ & $107(100)$ \\
\hline & SCF-religated & 95 & $0(0.0)$ & $0(0.0)$ & $95(100)$ \\
\hline
\end{tabular}

MPN: male pronuclei, FPN: female pronuclei.

Table 4. MCM7 and ORC2 expression at $9 \mathrm{~h}$ after vas deferens sperm injection into mouse oocyte (During DNA synthesis)

\begin{tabular}{|c|c|c|c|c|c|}
\hline & \multirow[b]{2}{*}{ Group } & \multirow{2}{*}{$\begin{array}{l}\text { No. of injected } \\
\text { oocytes }\end{array}$} & \multicolumn{3}{|c|}{ No. of zygotes (\%) } \\
\hline & & & $\begin{array}{l}\text { Stained with } \\
\text { MPN only }\end{array}$ & $\begin{array}{l}\text { Stained with } \\
\text { FPN only }\end{array}$ & $\begin{array}{l}\text { Stained with } \\
\text { MPN and FPN }\end{array}$ \\
\hline \multirow{3}{*}{ MCM7 } & Control & 104 & $0(0.0)$ & $0(0.0)$ & $104(100)$ \\
\hline & SCF & 97 & $0(0.0)$ & $0(0.0)$ & $97(100)$ \\
\hline & SCF-religated & 115 & $0(0.0)$ & $0(0.0)$ & $115(100)$ \\
\hline \multirow{3}{*}{ ORC2 } & Control & 105 & $0(0.0)$ & $0(0.0)$ & $105(100)$ \\
\hline & SCF & 105 & $0(0.0)$ & $0(0.0)$ & $105(100)$ \\
\hline & SCF-religated & 107 & $0(0.0)$ & $0(0.0)$ & $107(100)$ \\
\hline
\end{tabular}

MPN: male pronuclei, FPN: female pronuclei.

각 관찰된 경우는 나타나지 않았다. 그리고 DNA 합성이 진행 중인 정자 주입 후 9시간째 Vas-SCF와 Vas-SCFreligated 그룹의 DAPI 염색을 보면 DNA degradation이 되 어 부계 전핵이 관찰되지 않았다.

\section{고 찰}

포유동물의 수정란이 DNA 손상에 대응하는 방식은 아 직 불분명하다. Gawecka (2012)의 연구 결과에 따르면 수 정란이 DNA 손상을 인식하고 DNA 복제 지연, 배아 발 달 지연 및 배아 발달 중기가 발생한다고 한다. 따라서 배 아 발달과정에 있어서 다른 수준, 다른 형태의 DNA 손상 에 반응하는 방식에 대한 이해는 향후 연구에 중요한 정 보를 제공할 것이고, 이는 새로운 세포 주기 정지 또는 세 포사멸 기전을 밝혀내는데 도움이 될 것이다. 본 연구는 DNA 손상에 따라 DNA 복제 개시에 앞서 일어나는 DNA 라이센싱의 차이와 수정란의 DNA 손상 인식 차이, 배아
발달의 차이를 연구하였다. 성숙한 정자에 2가 양이온인 $\mathrm{MnCl}_{2}$ 와 $\mathrm{CaCl}_{2}$ 을 처리하면 정자 DNA에서 이중나선 절단 이 일어나 $25 \sim 50 \mathrm{~kb}$ 크기로 SCF가 만들어지며(Yamauchi et al., 2007), 이러한 DNA 조각은 EDTA가 처리되면 다시 회복(SCF-religated)된다(Shaman et al., 2006). 또한 epididymal sperm과 vas deferens sperm은 핵산분해효소의 활성 차이로 SCF와 SCF-religated 정도가 다르다(Yamauchi et al., 2007). 따라서 epididymal sperm과 vas deferens sperm에 2 가 양이온을 처리하여 DNA 손상을 유발하였다. 그리고 이를 이용하여 만든 1 세포기 수정란에서 $\mathrm{MCM} 7$ 과 $\mathrm{ORC} 2$ 의 발 현 여부를 통해 정상적인 라이센싱이 일어나는지 알아보 았다.

$\mathrm{DNA}$ 복제 전 모든 그룹의 1 세포기 수정란에서 $100 \%$ 비율로 부계와 모계 전핵에서 $\mathrm{MCM} 7$ 과 $\mathrm{ORC} 2$ 가 발현되 었다(Table 1,2). 또한 DNA 복제 진행 중에도 모든 그룹 의 1 세포기 수정란에서 $100 \%$ 비율로 부계와 모계 전핵에 서 $\mathrm{MCM} 7$ 과 $\mathrm{ORC} 2$ 가 발현되었다(Table 3,4$)$. 이는 정자의 
DNA에 SCF 및 SCF-religated 손상이 일어나더라도 부계 와 모계 전핵의 DNA 복제기점에서 라이센싱은 정상적으 로 이루어졌음을 시사한다. 즉 1 세포기 수정란의 부계와 모계 전핵 내의 DNA 복제기점에서 이루어지는 라이센싱 진행에 DNA 손상이 영향을 끼치지 않는다고 결론을 내 릴 수 있었다.

또한 DNA 복제 진행 중에 Vas-SCF와 Vas-SCF-religated 그룹의 부계 전핵이 관찰되지 않고 degradation이 관찰되 었는데, Yamauchi의 연구 결과인 SCF가 일어난 정자를 주 입하면 부계 전핵에서 DNA 복제 시작 시 degradation된다 는 연구 결과와 일치하였다(Yamauchi et al., 2007).

결론적으로 DNA 복제 라이센싱 후 복제가 진행되면 DNA 복제 라이센싱은 DNA 손상 여부와 관계가 없지만 그 이후 과정에서는 손상된 DNA의 복제를 방지하기 위 해 부계 전핵에서 전형적인 세포자살경로와는 다른 기작 이 존재하는 것으로 생각되며, 이에 대한 구체적인 경로 파악을 위한 추가 연구가 필요한 것으로 판단된다.

\section{ACKNOWLEDGEMENTS}

This study was financially supported by Chonnam National University, 2014.

\section{CONFLICT OF INTEREST}

The authors have no conflicts of interest to disclose.

\section{REFERENCES}

Blow JJ. Preventing re-replication of DNA in a single cell cycle: evidence for a replication licensing factor. Journal of Cell Biology. 1993. 122: 993-1002.

Blow JJ, Laskey RA. A role for the nuclear envelope in controlling DNA replication within the cell cycle. Nature. 1988. 332: 546 $-548$.

Costa S, Blow JJ. The elusive determinants of replication origins. EMBO Reports. 2007. 8: 332-334.

Coster G, Frigola J, Beuron F, Morris EP, Diffley JF. Origin licensing requires ATP binding and hydrolysis by the MCM replicative helicase. Molecular Cell. 2014. 55: 666-677.

DePamphilis ML. Cell cycle dependent regulation of the origin recognition complex. Cell Cycle. 2005. 4: 70-79.

Gawecka JE, Marh J, Ortega M, Yamauchi Y, Ward MA, Ward WS. Mouse zygotes respond to severe sperm DNA damage by delaying paternal DNA replication and embryonic development.
PLOS One. 2013. 8: e56385.

Gilbert DM. Making sense of eukaryotic DNA replication origins Science. 2001. 294: 96-100.

Ghosh S, Vassilev AP, Zhang J, Zhao Y, DePamphilis ML. Assembly of the human origin recognition complex occurs through independent nuclear localization of its components. Journal of Biological Chemistry. 2011. 286: 23831-23841.

Krude T. Initiation of chromosomal DNA replication in mammalian cell-free systems. Cell Cycle. 2006. 5: 2115-2122.

Lemon KP, Grossman AD. Localization of bacterial DNA polymerase: evidence for a factory model of replication. Science. 1998. 282: 1516-1519.

Leno GH, Downes CS, Laskey RA. The nuclear membrane prevents replication of human G2 nuclei but not G1 nuclei in Xenopus egg extract. Cell. 1992. 69: 151-158.

Pardoll DM, Vogelstein B, Coffey DS. A fixed site of DNA replication in eukaryotic cells. Cell. 1980. 19: 527-536.

Rao H, Stillman B. The origin recognition complex interacts with a bipartite DNA binding site within yeast replicators. Proceedings of the National Academy of Sciences of the United States of America. 1995. 92: 2224-2228.

Robinson NP, Bell SD. Origins of DNA replication in the three domains of life. FEBS Journal. 2005. 272: 3757-3766.

Rowley A, Cocker JH, Harwood J, Diffley JF. Initiation complex assembly at budding yeast replication origins begins with the recognition of a bipartite sequence by limiting amounts of the initiator. The EMBO Journal. 1995. 14: 2631-2641.

Shaman JA, Prisztoka R, Ward WS. Topoisomerase IIB and an extracellular nuclease interact to digest sperm DNA in an apoptotic-like manner. Biology of Reproduction. 2006. 75: 741 -748 .

Speck C, Chen Z, Li H, Stillman B. ATPase-dependent cooperative binding of ORC and Cdc6 to origin DNA. Nature Structural \& Molecular Biology. 2005. 12: 965-971.

Stubblefield E. Analysis of the replication pattern of chinese hamster chromosomes using 5-bromodeoxyuridine suppression of 33258 hoechst fluorescence. Chromosome. 1975. 53: 209-221.

Szczygiel M, Yanagimachi R. Intracytoplasmic sperm injection. In: Nagy A, Gertsenstein M, Vintersten K, Behringer R (eds.) Manipulation of the Mouse Embryo - A Laboratory Manual Cold Spring Harbor Laboratory Press. 2003.

Takeda DY, Dutta A. DNA replication and progression through S phase. Oncogene. 2005. 24: 2827-2843.

Takeda DY, Shibata Y, Parvin JD, Dutta A. Recruitment of ORC or CDC6 to DNA is sufficient to create an artificial origin of 
replication in mammalian cells. Genes \& Development. 2005. 19: 2827-2836.

Thomae AW, Pich D, Brocher J, Spindler MP, Berens C, Hock R, Hammerschmidt W, Schepers A. Interaction between HMGA1a and the origin recognition complex creates site-specific replication origins. Proceedings of the National Academy of Sciences of the United States of America. 2008. 105: 1692-1697.

Ticau S, Friedman LJ, Ivica NA, Gelles J, Bell SP. Single molecule studies of origin licensing reveal mechanisms ensuring bidirectional helicase loading. Cell. 2015. 161: 513-525.

Yamauchi YS, Shaman JA, Boaz SM, Ward WS. Paternal pronuclear DNA degradation is functionally linked to DNA replication in mouse oocyte. Biology of Reproduction. 2007. 77: 407-415.

Yamauchi Y, Shaman JA, Ward WS. Topoisomerase II-mediated breaks in spermatozoa cause the specific degradation of paternal DNA in fertilized oocytes. Biology of Reproduction. 2007. 76: 666-672.

Vogelstein B, Pardoll DM, Coffey DS. Supercoiled loops and eucaryotic DNA replicaton. Cell. 1980. 22: 79-85.

https://doi.org/10.15616/BSL.2017.23.4.372

Cite this article as: CJ Kim, TH Kim, EW Lee, KB Lee. Evidence of DNA Replication Licensing and Paternal DNA Degradation by MCM7 and ORC2 in the Mouse One-cell Embryo. Biomedical Science Letters. 2017. 23: 372-379. 